\title{
Effective Oxygen-Defect Passivation in ZnO Thin Films Prepared by Atomic Layer Deposition Using Hydrogen Peroxide
}

\author{
Yue Wang, Kyung-Mun Kang, Minjae Kim, and Hyung-Ho Park $(\mathbb{1}+\dot{ }$ \\ Department of Materials Science and Engineering, Yonsei University, Seoul 03722, Korea \\ (Received April 30, 2019; Revised May 13, 2019; Accepted May 14, 2019)
}

\begin{abstract}
The intrinsic oxygen-vacancy defects in $\mathrm{ZnO}$ have prevented the preparation of p-type $\mathrm{ZnO}$ with high carrier concentration. Therefore, in this work, the effect of the concentration of $\mathrm{H}_{2} \mathrm{O}_{2}$ (used as an oxygen source) on the oxygen-vacancy concentration in $\mathrm{ZnO}$ prepared by atomic layer deposition was investigated. The results indicated that the oxygen-vacancy concentration in the $\mathrm{ZnO}$ film decreased by the oxygen-rich growth conditions when using $\mathrm{H}_{2} \mathrm{O}_{2}$ as the oxygen precursor instead of a conventional oxygen source such as $\mathrm{H}_{2} \mathrm{O}$. The suppression of oxygen vacancies decreased the carrier concentration and increased the resistivity. Moreover, the growth orientation changed to the (002) plane, from the combined (100) and (002) planes, with the increase in $\mathrm{H}_{2} \mathrm{O}_{2}$ concentration. The passivation of oxygen-vacancy defects in $\mathrm{ZnO}$ can contribute to the preparation of $\mathrm{p}$-type $\mathrm{ZnO}$.
\end{abstract}

Key words : $\mathrm{ZnO}, \mathrm{ALD}, \mathrm{H}_{2} \mathrm{O}_{2}$, Oxygen vacancy

\section{Introduction}

$\mathrm{Z}$ inc oxide $(\mathrm{ZnO})$ is a semiconductor material with a direct bandgap energy of $3.37 \mathrm{eV}$ and exciton binding energy of $60 \mathrm{meV}$. ZnO has attracted remarkable attention owing to its outstanding optoelectronic properties and wide application scope ${ }^{1-4)}$ including light-emitting diode (LED) displays, ${ }^{5,6)}$ field-effect transistors, ${ }^{7)}$ photodetectors, ${ }^{8,9)}$ artificial intelligence, ${ }^{10)}$ and solar cells. ${ }^{11)}$ High-quality homogeneous p-n junctions (composed of high-quality n-type and p-type $\mathrm{ZnO}$ ) are necessary for the realization of ZnO-based LEDs. Recently, n-type $\mathrm{ZnO}$ with high carrier concentration, high Hall mobility, and low resistivity could be prepared using various doping elements (doping with $\mathrm{Cl}, \mathrm{Ti}, \mathrm{Al}, \mathrm{Ga}$, and $\mathrm{N}) .{ }^{12-16)}$ However, the preparation of $\mathrm{p}$-type $\mathrm{ZnO}$ with high carrier concentration and conductivity remains an unsolved problem, which prevents the commercial application of ZnO-based LEDs. ${ }^{4,17)}$ The presence of oxygen vacancies $\left(\mathrm{V}_{\mathrm{o}}\right)$ in $\mathrm{ZnO}$ is one of the main barriers to preparing high-quality p-type $\mathrm{ZnO}$. Because $\mathrm{V}_{\mathrm{o}}$ is an n-type defect and can be easily formed during $\mathrm{ZnO}$ formation, the as-prepared $\mathrm{ZnO}$ films usually exhibit $\mathrm{n}$-type semiconducting behavior. ${ }^{17,18)}$ Moreover, $\mathrm{V}_{\mathrm{o}}$ can counteract the acceptor dopants in $\mathrm{ZnO}$, which is one of the main reasons why p-type $\mathrm{ZnO}$ with high hole concentrations is difficult to prepare. ${ }^{17,18)}$ Therefore, to enable the fabrication of high-performance p-type $\mathrm{ZnO}$ films, it is important to investigate the suppression of $V_{o}$ in

Corresponding author : Hyung-Ho Park

E-mail : hhpark@yonsei.ac.kr

Tel : +82-2-2123-2853 Fax : +82-2-312-5375

ORCID

https://orcid.org/0000-0001-5540-5433
$\mathrm{ZnO}$ films.

Previous theoretical studies have shown that $\mathrm{V}_{\mathrm{o}}$ can be formed easily in oxygen-deficient preparation conditions; it can also be passivated under oxygen-rich (O-rich) preparation conditions. ${ }^{17,19)} \mathrm{Ma}$ et al. reported that a higher induced oxygen partial pressure could reduce the $\mathrm{V}_{\mathrm{o}}$ in $\mathrm{ZnO}$ films prepared by vapor-phase epitaxy. ${ }^{20)} \mathrm{Yu}$ et al. showed that the concentration of oxygen vacancies in the $\mathrm{ZnO}$ films prepared by pulsed-laser deposition could be decreased by increasing the oxygen partial pressure. ${ }^{21)}$ Both Xiong et al. and Singh et al. proved that n-type $\mathrm{ZnO}$ could transform to p-type $\mathrm{ZnO}$ upon increasing the oxygen partial pressure, in the sputtering deposition method. ${ }^{22,23)}$ Post-annealing is a method commonly used to remove the $\mathrm{V}_{\mathrm{o}}$ in the as-prepared $\mathrm{ZnO}$, and $\mathrm{V}_{\mathrm{o}}$ showed the maximum reduction when annealing in $\mathrm{O}_{2}$, when compared to other annealing gases such as air, $\mathrm{H}_{2}, \mathrm{~N}_{2}$, and $\mathrm{Ar} .^{21,24-26)}$ The above-mentioned theoretical and experimental research results indicated that the amount of $\mathrm{V}_{\mathrm{o}}$ in $\mathrm{ZnO}$ could be modulated by controlling the conditions of the oxygen environment during the preparation and post-annealing stages. For the preparation of $\mathrm{ZnO}$ using the atomic layer deposition (ALD) method, diethylzinc (DEZ) and $\mathrm{H}_{2} \mathrm{O}$ are commonly used as the zinc source and oxygen source, respectively. $\mathrm{H}_{2} \mathrm{O}_{2}$ with a higher stoichiometric ratio of oxygen than $\mathrm{H}_{2} \mathrm{O}$ is a potential oxygen source that can provide more oxygen than $\mathrm{H}_{2} \mathrm{O}$, for the preparation of $\mathrm{ZnO}$ using $\mathrm{ALD} . \mathrm{H}_{2} \mathrm{O}_{2}$ of different concentrations (30\%-50\%) has been used for the preparation of $\mathrm{ZnO}$ and $\mathrm{TiO}_{2}$ using the ALD method. ${ }^{27-31)}$ However, there has been no detailed report on how the $\mathrm{H}_{2} \mathrm{O}_{2}$ concentration influences the amount of $\mathrm{V}_{\mathrm{o}}$ and the properties of the $\mathrm{ZnO}$ films produced using this method. Therefore, in this work, we focus on $\mathrm{V}_{\mathrm{o}}$ passivation and the related optoelectronic 
properties dependent on the different $\mathrm{H}_{2} \mathrm{O}_{2}$ concentrations used in the ALD method. ALD is a method, by which films can be grown in a layer-by-layer manner, by virtue of its mechanism of self-limiting chemical reaction. Furthermore, the film thickness can be controlled to a desired value by controlling the number of ALD deposition cycles. ALD can be used prepare uniform films with excellent step coverage on substrates with complex structures. ${ }^{32}$

\section{Experiment Procedure}

\subsection{ALD deposition parameters}

ALD was performed using a traveling-wave-type Lucida D100 system (NCD Technology, Inc., Korea), and ZnO films were prepared on both liquid crystal display (LCD) glass (Fusion 1737) and Si substrates, for measuring various properties. DEZ (Hansol Chemical Co., Ltd., Korea) was used as the $\mathrm{Zn}$ precursor and different concentrations of $\mathrm{H}_{2} \mathrm{O}_{2}(50 \%, 40 \%, 30 \%, 20 \%, 10 \%$, and $0 \%)$ prepared using deionized water and $50 \% \mathrm{H}_{2} \mathrm{O}_{2}\left(50 \%\right.$ in $\mathrm{H}_{2} \mathrm{O}$, Sigma-Aldrich) was used as the $\mathrm{O}$ source. The DEZ and deionized water/ $\mathrm{H}_{2} \mathrm{O}_{2}$ were maintained at $10^{\circ} \mathrm{C}$ (using a chiller) and room temperature, respectively. $\mathrm{N}_{2}(99.999 \%)$ gas with a flow rate of $20 \mathrm{sccm} / \mathrm{min}$ was used as both the purge gas and transport gas. The ALD dosing schedule of precursors, to prepare the $\mathrm{ZnO}$ thin films, was as follows: i) DEZ for $0.1 \mathrm{~s}$, ii) $\mathrm{N}_{2}$ for $10 \mathrm{~s}$, iii) $\mathrm{H}_{2} \mathrm{O} / \mathrm{H}_{2} \mathrm{O}_{2}$ for $0.1 \mathrm{~s}$, and iv) $\mathrm{N}_{2}$ for $10 \mathrm{~s}$. All samples were deposited at a substrate temperature of $150^{\circ} \mathrm{C}$, and 1200 deposition cycles were performed. The samples prepared using different concentrations of $\mathrm{H}_{2} \mathrm{O}_{2}$ were labeled as $\mathrm{ZnO}-\mathrm{H}_{2} \mathrm{O}_{2}-0 \%, \mathrm{ZnO}-\mathrm{H}_{2} \mathrm{O}_{2}-10 \%, \mathrm{ZnO}-\mathrm{H}_{2} \mathrm{O}_{2}-20 \%, \mathrm{ZnO}-\mathrm{H}_{2} \mathrm{O}_{2}-$ $30 \%, \mathrm{ZnO}-\mathrm{H}_{2} \mathrm{O}_{2}-40 \%$, and $\mathrm{ZnO}-\mathrm{H}_{2} \mathrm{O}_{2}-50 \%$.

\subsection{Characterization methods}

The crystal structures of the ALD-prepared $\mathrm{ZnO}$ thin films were verified using X-ray diffraction (XRD, D/MAX2000, Rigaku) with $\mathrm{Cu}-\mathrm{K} \alpha$ radiation $(\lambda=0.154 \mathrm{~nm})$. The surface morphology was measured by field-emission scanning-electron microscopy (FE-SEM, JEOL, JSM 7001F). Photoluminescence (PL) spectroscopy (LabRam Aramis, Horriba Jovin Yvon) was conducted with $325 \mathrm{~nm}$ laser excitation at room temperature. The electrical properties were investigated using Hall-effect measurement (Ecopia HMS3000) at room temperature.

\section{Results and Discussion}

\subsection{Growth orientation and crystallinity properties}

Figure 1 shows the XRD patterns of the $\mathrm{ZnO}-\mathrm{H}_{2} \mathrm{O}_{2}$ thin films prepared using different concentrations of $\mathrm{H}_{2} \mathrm{O}_{2}$. Two diffraction peaks at $2 \theta$ values of $31.93^{\circ}$ and $34.55^{\circ}$ were observed in the $\mathrm{ZnO}-\mathrm{H}_{2} \mathrm{O}_{2}-0 \%$ sample. These two diffraction peaks corresponded to the (100) and (002) planes of the hexagonal wurtzite structure of $\mathrm{ZnO}$. On increasing the $\mathrm{H}_{2} \mathrm{O}_{2}$ concentration, the (100) and (002) diffraction peaks were found to be suppressed in the $\mathrm{ZnO}-\mathrm{H}_{2} \mathrm{O}_{2}-10 \%$ and a very

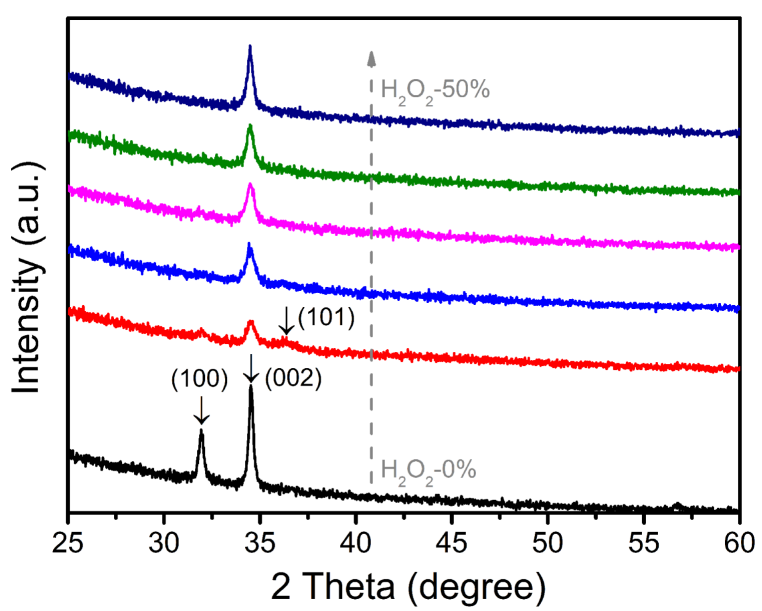

Fig. 1. X-ray diffraction (XRD) patterns of $\mathrm{ZnO}-\mathrm{H}_{2} \mathrm{O}_{2}$ thin films for different concentrations of $\mathrm{H}_{2} \mathrm{O}_{2}(0 \%, 10 \%$, $20 \%, 30 \%, 40 \%$, and $50 \%$ ).

weak (101) diffraction peak was observed at a $2 \theta$ value of $36.27^{\circ}$. When the concentration of $\mathrm{H}_{2} \mathrm{O}_{2}$ was greater than $20 \%$, only the (002) diffraction peak was observed, and the intensity of this (002) diffraction peak increased on increasing the $\mathrm{H}_{2} \mathrm{O}_{2}$ concentration. The above results show that the growth orientation of the $\mathrm{ZnO}$ thin films changed from the (100) and (002) planes to a single (002) plane, with the increase in $\mathrm{H}_{2} \mathrm{O}_{2}$ concentration up to $50 \%$. Previous works had also observed the preferred growth orientation of (002) in $\mathrm{ZnO}$ thin films prepared by the ALD method using DEZ and $\mathrm{H}_{2} \mathrm{O}_{2}$ with concentrations of 30 to $50 \%{ }^{28,30,31)}$ For ALDprepared $\mathrm{ZnO}$ prepared using $\mathrm{DEZ}$ and $\mathrm{H}_{2} \mathrm{O}$, normally, the growth orientation corresponds to the mixed planes of (100) and (002). ${ }^{12)}$ A previous work had suggested that the preferred growth orientation of the ALD-prepared $\mathrm{ZnO}$ films could be controlled by controlling the oxygen precursor, and that the transformation from the (100) to (002) growth orientation could be achieved by pulsing additional oxygen gas before pulsing $\mathrm{H}_{2} \mathrm{O}{ }^{33)}$ The feeding of extra oxygen gas before $\mathrm{H}_{2} \mathrm{O}$ feeding could supply more oxygen, in contrast to a single $\mathrm{H}_{2} \mathrm{O}$ feeding in a single dosing step, which meant that the feeding of a more oxygen-rich source (O-rich environment) could change the preferred growth orientation from the (100) to (002) plane. Therefore, the change in the preferred orientation, from the coexistence of the (100) and (002) planes to the existence of a unique (002) plane, with the increase in the $\mathrm{H}_{2} \mathrm{O}_{2}$ concentration, could be attributed to the increase of oxygen in the ALD chamber. For the $\mathrm{ZnO}$ $\mathrm{H}_{2} \mathrm{O}_{2}-0 \%\left(\mathrm{ZnO}-\mathrm{H}_{2} \mathrm{O}\right)$ system, the higher (002) XRD intensity (compared to the XRD intensity of the $\mathrm{ZnO}-\mathrm{H}_{2} \mathrm{O}_{2}-(10 \%$ to $50 \%$ ) system) could be attributed to the higher film crystallinity in the former than in the latter, as predicted in previous works. ${ }^{30,31)}$ For the $\mathrm{ZnO}-\mathrm{H}_{2} \mathrm{O}_{2}-(10 \%$ to $50 \%)$ systems, the increased concentration of $\mathrm{H}_{2} \mathrm{O}_{2}$ could result in an enhanced oxygen-rich environment, which could further lead to an enhanced (002) XRD diffraction intensity. ${ }^{33)}$ The low XRD intensity in the $\mathrm{ZnO}-\mathrm{H}_{2} \mathrm{O}_{2}-10 \%$ and $\mathrm{ZnO}-\mathrm{H}_{2} \mathrm{O}_{2}$ - 
$20 \%$ samples could also be attributed to their transition stages in the transition process from the coexistence of (100) and (002) to the existence of a unique (002)-oriented $\mathrm{ZnO}$ film.

For the wurtzite-structure $\mathrm{ZnO}$, the c-axis (002) plane has the highest stacking density and lowest surface energy, indicating that the (002) growth orientation is the thermodynamically favored and preferred orientation, theoretically. ${ }^{34)}$ The mixture of (100) and (002) growth orientations in $\mathrm{ZnO}-\mathrm{H}_{2} \mathrm{O}_{2}-0 \%$ implies that the growth of the (002) plane is suppressed, for example, as a result of the adsorption of $\mathrm{CH}_{3}^{-}$or $\mathrm{CH}_{3} \mathrm{CH}_{2}^{-}$, which are dissociated from the ethyl groups of DEZ. ${ }^{35)}$ This type of adsorption can be suppressed at high substrate temperatures by the resolution of $\mathrm{CH}_{3}{ }^{-}$ and $\mathrm{CH}_{3} \mathrm{CH}_{2}^{-}$, resulting in $\mathrm{ZnO}$ films with (002) plane growth orientation. ${ }^{35)}$ A previous study had shown that $\mathrm{H}_{2} \mathrm{O}_{2}$ has a higher efficiency in cleaning the residual species in the ALD system than $\mathrm{H}_{2} \mathrm{O}$. ${ }^{36)}$ This can be another reason contributing to the change in the preferred growth orientation of $\mathrm{ZnO}$, from mixed planes of (100) and (002) to a single (002) plane, upon increasing the $\mathrm{H}_{2} \mathrm{O}_{2}$ concentration.

\subsection{Surface morphology properties}

Figure 2 shows the FE-SEM images of the $\mathrm{ZnO}$ thin films prepared using different concentrations of $\mathrm{H}_{2} \mathrm{O}_{2}$. In the case of $\mathrm{ZnO}$ thin films, grains with the (100) and (002) growth orientations generally have wedge-shaped and columnshaped surfaces, respectively. ${ }^{33)}$ As shown in Fig. 2, the $\mathrm{ZnO}-\mathrm{H}_{2} \mathrm{O}_{2}-0 \%$ sample has a mixed surface morphology of wedge-like and columnar (Fig. 2(a)). A transition of surface morphology to the (002) columnar-dominated morphology can be observed in the $\mathrm{ZnO}-\mathrm{H}_{2} \mathrm{O}_{2}-20 \%$ sample (Fig. 2(c)). Figs. 2(d) to 2(f) show the surface morphologies of the $\mathrm{ZnO}$ $\mathrm{H}_{2} \mathrm{O}_{2}-30 \%$, $\mathrm{ZnO}-\mathrm{H}_{2} \mathrm{O}_{2}-40 \%$, and $\mathrm{ZnO}-\mathrm{H}_{2} \mathrm{O}_{2}-50 \%$ samples, with complete and uniform columnar structures. The above results in the FE-SEM images are consistent with the XRD results in Fig. 1, and it can be inferred that the increase in the $\mathrm{H}_{2} \mathrm{O}_{2}$ concentration from $0 \%$ to $50 \%$ induces an increase in the oxygen concentration in the ALD chamber for $\mathrm{ZnO}$ thin-film growth. This oxygen-rich growth condition results in a growth orientation change to (002), depending on the surface energy.

\subsection{Photoluminescence properties}

Previous studies had indicated that PL analysis is a useful method for studying defect types in $\mathrm{ZnO}$. For example, it has been shown that the green emission at approximately $550 \mathrm{~nm}$ can be attributed to the presence of $\mathrm{V}_{\mathrm{o}}$ and zinc interstitials $\left(\mathrm{Zn}_{\mathrm{i}}\right),{ }^{37-39)}$ while the yellow emission at approximately $585 \mathrm{~nm}$ may be induced by oxygen interstitials $\left(\mathrm{O}_{\mathrm{i}}\right)$ and $\mathrm{Zn}_{\mathrm{i}}$, and the orange-red emission from $600 \mathrm{~nm}$ to 750 $\mathrm{nm}$ may be attributed to the $\mathrm{O}_{i}$ and oxygen anti-sites $\left(\mathrm{O}_{\mathrm{Zn}}\right) \cdot{ }^{37-39)}$ Therefore, to study the effect of different $\mathrm{H}_{2} \mathrm{O}_{2}$ concentrations on $\mathrm{V}_{\mathrm{o}}$ in $\mathrm{ZnO}$ films, the PL spectra of all samples were analyzed at room temperature in the wavelength range from $300 \mathrm{~nm}$ to $700 \mathrm{~nm}$. As shown in Fig. 3, two PL emission peaks were observed in all $\mathrm{ZnO}$ films. The emission peak located at approximately $375 \mathrm{~nm}$ could be

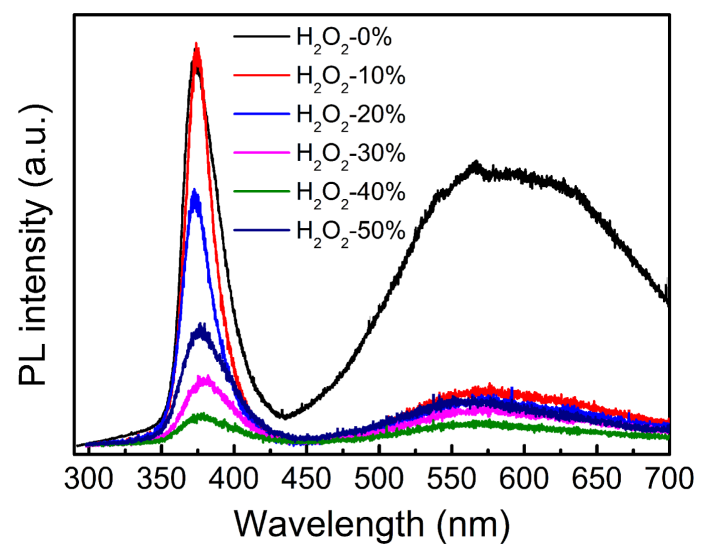

Fig. 3. Photoluminescence (PL) spectra of $\mathrm{ZnO}$ films with different $\mathrm{H}_{2} \mathrm{O}_{2}$ concentrations.
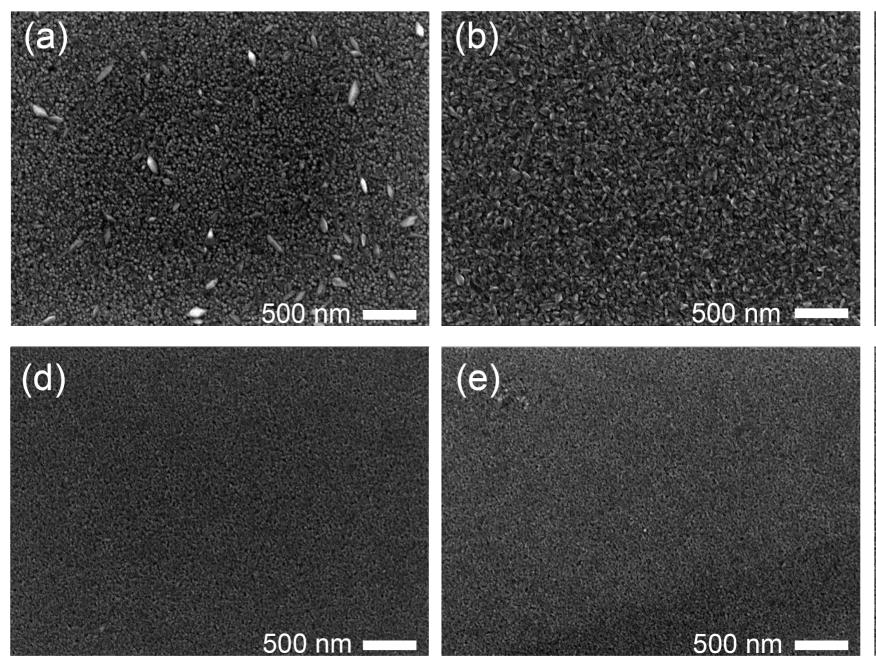
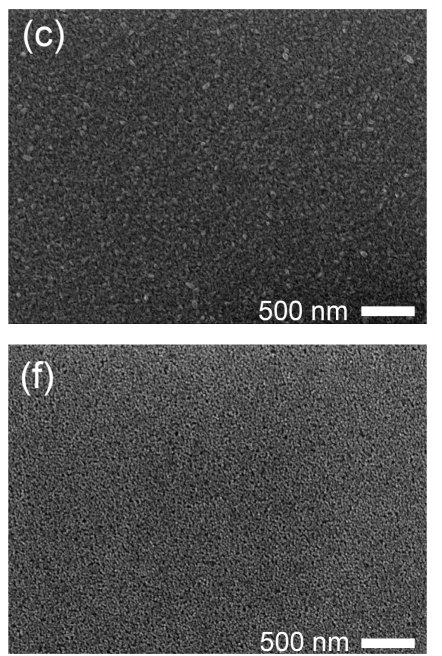

Fig. 2. Field-emission scanning electron microscopy (FE-SEM) images of (a) $\mathrm{ZnO}-\mathrm{H}_{2} \mathrm{O}_{2}-0 \%$, (b) $\mathrm{ZnO}-\mathrm{H}_{2} \mathrm{O}_{2}-10 \%$, (c) $\mathrm{ZnO}-\mathrm{H}_{2} \mathrm{O}_{2}-20 \%$, (d) $\mathrm{ZnO}-\mathrm{H}_{2} \mathrm{O}_{2}-30 \%$, (e) $\mathrm{ZnO}-\mathrm{H}_{2} \mathrm{O}_{2}-40 \%$, and (f) $\mathrm{ZnO}-\mathrm{H}_{2} \mathrm{O}_{2}-50 \%$. 
attributed to the well-known UV near-band-edge (NBE) emission. The broad emission peaks in the range of approximately 540 to $630 \mathrm{~nm}$ could have been caused by the presence of oxygen and zinc-related defects such as $\mathrm{V}_{\mathrm{o}}$ and $\mathrm{Zn}_{\mathrm{i}}$. Compared to the $\mathrm{ZnO}-\mathrm{H}_{2} \mathrm{O}_{2}-0 \%$ sample, the intensity of the broad emission peak (540 to $630 \mathrm{~nm}$ ) was decreased remarkably in all $\mathrm{ZnO}-\mathrm{H}_{2} \mathrm{O}_{2}$ films. Previous results had indicated that the use of $\mathrm{H}_{2} \mathrm{O}_{2}$ as an oxygen precursor could provide an O-rich growth environment and could passivate the formation of $\mathrm{V}_{\mathrm{o}} \cdot{ }^{30,31)} \mathrm{A}$ decrease in the PL emission intensity at approximately 540 to $630 \mathrm{~nm}$ indicated a decrease in the oxygen and zinc-related defects. Additional analyses with the Hall properties of carrier concentration are provided in the next section. A slight increase in the PL intensity at approximately 540 to $630 \mathrm{~nm}$, with the increase in the $\mathrm{H}_{2} \mathrm{O}_{2}$
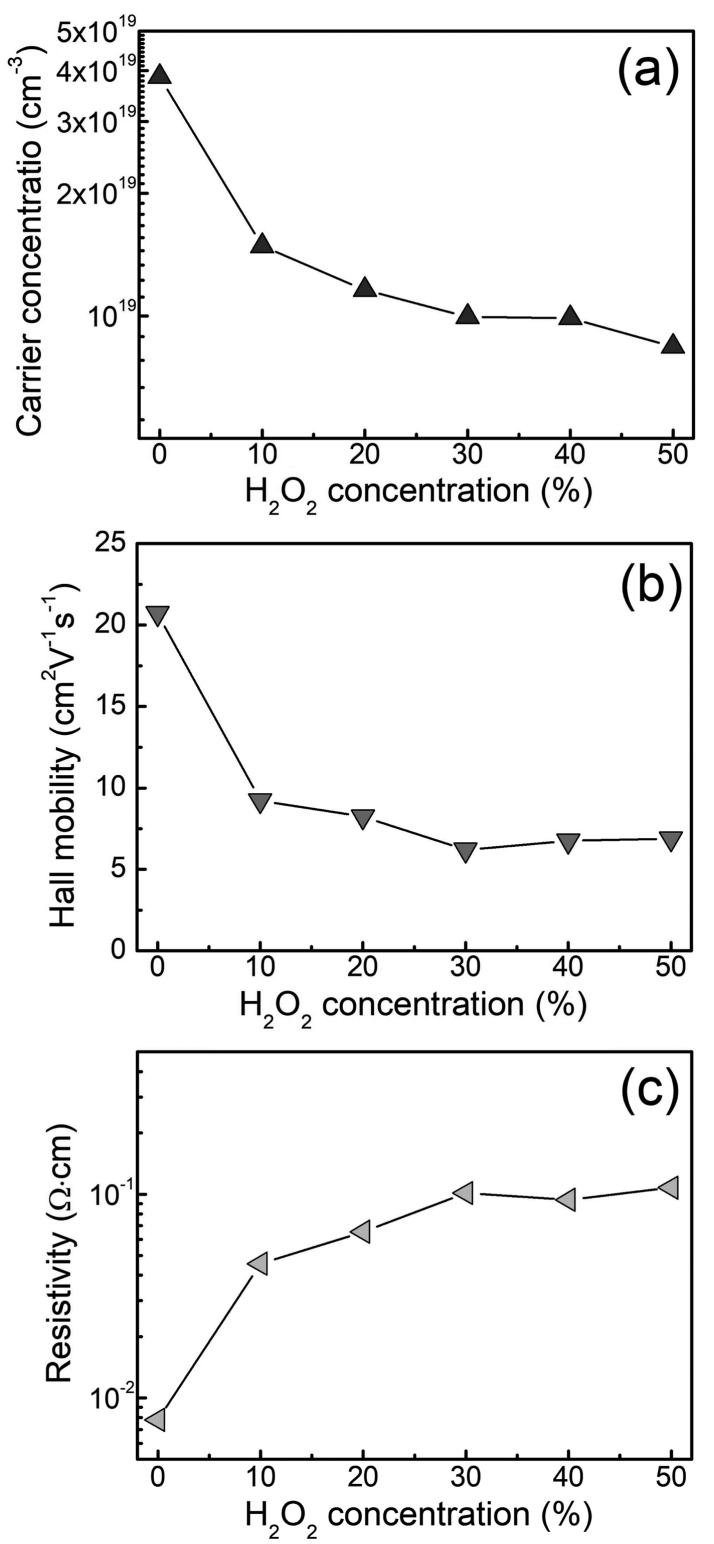

Fig. 4. (a) Carrier concentration, (b) Hall mobility, and (c) resistivity of the $\mathrm{ZnO}-\mathrm{H}_{2} \mathrm{O}_{2}$ films for different $\mathrm{H}_{2} \mathrm{O}_{2}$ concentrations ranging from $0 \%$ to $50 \%$. concentration from 30 and $40 \%$ to $50 \%$, could be explained by the increased film crystallinity, as shown in Fig. $1 .{ }^{40)}$

\subsection{Electrical properties}

The as-prepared $\mathrm{ZnO}$ film normally has n-type characteristics because of the effects of the n-type $\mathrm{V}_{\mathrm{o}}$ defects in $\mathrm{ZnO}$, as similar to the other defects in semiconductors, the concentration of $\mathrm{V}_{\mathrm{o}}$ in $\mathrm{ZnO}$ can also influence the electrical properties of the semiconductor $\mathrm{ZnO}$. Previous studies had shown that the decrease in the $\mathrm{V}_{\mathrm{o}}$ concentration in $\mathrm{ZnO}$ films, caused by post-annealing in oxygen atmosphere and increasing the oxygen partial pressure in the preparation process, could result in a decrease in the carrier concentration and increase in the resistivity. ${ }^{20,26)}$ As a result, the use of $\mathrm{H}_{2} \mathrm{O}_{2}$ instead of ALD oxygen precursor $\mathrm{H}_{2} \mathrm{O}$ could inhibit the formation of $\mathrm{V}_{\mathrm{o}}$ in the $\mathrm{ZnO}$ films. ${ }^{18,19)}$ Therefore, the electrical properties of the $\mathrm{ZnO}$ film were investigated for different $\mathrm{H}_{2} \mathrm{O}_{2}$ concentrations. Fig. 4 shows the carrier concentration (a), Hall mobility (b), and resistivity (c) of the $\mathrm{ZnO}-\mathrm{H}_{2} \mathrm{O}_{2}$ films for different $\mathrm{H}_{2} \mathrm{O}_{2}$ concentrations. With the increase in the $\mathrm{H}_{2} \mathrm{O}_{2}$ concentration from $0 \%$ to $50 \%$, Fig. 4 (a) and (b) show a decrease in the carrier concentration and mobility $\left(\mathrm{H}_{2} \mathrm{O}_{2}: 0 \%\right.$ to $\left.30 \%\right)$ followed by a slight increase in the mobility $\left(\mathrm{H}_{2} \mathrm{O}_{2}: 30 \%\right.$ to $\left.50 \%\right)$. The decreased carrier concentration could be attributed to the decrease in the $\mathrm{V}_{\mathrm{o}}$ and $\mathrm{Zn}_{\mathrm{i}}$ concentrations, as the n-type defects in the $\mathrm{ZnO}$ film could serve as sources of carrier generation. The decreased carrier mobility in the $\mathrm{ZnO}$ films using $\mathrm{H}_{2} \mathrm{O}_{2}$, when compared to the $\mathrm{ZnO}-\mathrm{H}_{2} \mathrm{O}_{2}-0 \%$ sample with only $\mathrm{H}_{2} \mathrm{O}$, could be attributed to a decrease in the film crystallinity, as shown in Fig. 1. A slight increase in the carrier mobility as the $\mathrm{H}_{2} \mathrm{O}_{2}$ concentration increased from $30 \%$ to $50 \%$ could be caused by the slight increase in the film crystallinity, as predicted in Fig. 1. Therefore, the use of $\mathrm{H}_{2} \mathrm{O}_{2}$ in the ALD oxygen precursor could lead to a decrease in $\mathrm{V}_{\mathrm{o}}$ and reduce the carrier concentration. Fig. 4(c) shows that the resistivity of the $\mathrm{ZnO}-\mathrm{H}_{2} \mathrm{O}_{2}$ films increases with the increase in $\mathrm{H}_{2} \mathrm{O}_{2}$ concentration due to the decrease in the carrier concentration.

\section{Conclusions}

$\mathrm{ZnO}$ thin films were prepared using the ALD method with DEZ and $\mathrm{H}_{2} \mathrm{O}_{2}$, with different $\mathrm{H}_{2} \mathrm{O}_{2}$ concentrations ranging from 0 to $50 \%$. The results showed that some properties of the $\mathrm{ZnO}$ thin films changed upon increasing the $\mathrm{H}_{2} \mathrm{O}_{2}$ concentration from 0 to $50 \%$. The growth orientation and surface morphology of the $\mathrm{ZnO}$ thin films changed, from coexistence of wedge-like (100) and columnar (002) planes to the existence of a single columnar (002) plane. The film crystallinity increased as the $\mathrm{H}_{2} \mathrm{O}_{2}$ concentration increased from 10 to $50 \%$. The PL emission intensity at approximately 540 to $630 \mathrm{~nm}$ was clearly decreased. This could be due to the passivation of the n-type defects, most probably $V_{o}$ and $\mathrm{Zn}_{\mathrm{i}}$. The changes in the PL intensity were related to the decrease in the carrier concentration and increase in the 
electrical resistivity. The passivation of $n$-type defects such as $\mathrm{V}_{\mathrm{o}}$ and $\mathrm{Zn}_{\mathrm{i}}$ in $\mathrm{ZnO}$ is helpful for the preparation of p-type $\mathrm{ZnO}$ with high carrier concentration and improved performance, which is suitable for use in $\mathrm{ZnO}$-based devices.

\section{Acknowledgments}

This manuscript was based on the work "Development of Mott-transition based forming-less non-volatile resistive switching memory \& array", supported by the Ministry of Trade, Industry \& Energy (MOTIE, Korea) under the Industrial Strategic Technology Development Program No. 10068075. Yue Wang thanks the China Scholarship Council (CSC) for financial support.

\section{REFERENCES}

1. H. Saarenpää, T. Niemi, A. Tukiainen, H. Lemmetyinen, and N. Tkachenko, "Aluminum Doped Zinc Oxide Films Grown by Atomic Layer Deposition for Organic Photovoltaic Devices," Sol. Energy Mater. Sol. Cells, 94 [8] 1379-83 (2010).

2. A. B. F. Martinson, J. W. Elam, J. T. Hupp, and M. J. Pellin, "ZnO Nanotube Based Dye-Sensitized Solar Cells," Nano Lett., 7 [8] 2183-87 (2007).

3. S.-H. K. Park, C.-S. Hwang, M. Ryu, S. Yang, C. Byun, J. Shin, J.-I. Lee, K. Lee, M. S. Oh, and S. Im, "Transparent and Photo-Stable ZnO Thin-Film Transistors to Drive an Active Matrix Organic-Light-Emitting-Diode Display Panel," Adv. Mater., 21 [6] 678-82 (2009).

4. J. C. Fan, K. M. Sreekanth, Z. Xie, S. L. Chang, and K. V. Rao, "p-Type ZnO Materials: Theory, Growth, Properties and Devices," Prog. Mater. Sci., 58 [6] 874-985 (2013).

5. S. Chu, G. P. Wang, W. H. Zhou, Y. P. Lin, L. Chernyak, J. Z. Zhao, J. Y. Kong, L. Li, J. J. Ren, and J. L. Liu, "Electrically Pumped Waveguide Lasing from ZnO Nanowires," Nat. Nanotechnol., 6 506-10 (2011).

6. R. Roöder, T. P. H. Sidiropoulos, C. Tessarek, S. Christiansen, R. F. Oulton, and C. Ronning, "Ultrafast Dynamics of Lasing Semiconductor Nanowires," Nano Lett., 15 [7] 4637-43 (2015).

7. X. F. Pan, X. Liu, A, Bermak, and Z. Y. Fan, "Self-Gating Effect Induced Large Performance Improvement of $\mathrm{ZnO}$ Nanocomb Gas Sensors," ACS Nano, 7 [10] 9318-24 (2013).

8. T. Y. Zhai, X. S. Fang, M. Y. Liao, X. J. Xu, H. B. Zeng, B. Yoshio, and D. A. Golberg, "Comprehensive Review of One-Dimensional Metal-Oxide Nanostructure Photodetectors," Sensors, 9 [8] 504 (2009).

9. D. Gedamu, I. Paulowicz, S. Kaps, O. Lupan, S. Wille, G. Haidarschin, Y. K. Mishra, and R. Adelung, "Rapid Fabrication Technique for Interpenetrated ZnO Nanotetrapod Networks for Fast UV Sensors," Adv. Mater., 26 [10] 1541-50 (2014).

10. Y. J. Lee, D. S. Ruby, D. W. Peters, B. B. McKenzie, and J. W. P. Hsu, "ZnO Nanostructures as Efficient Antireflection Layers in Solar Cells," Nano Lett., 8 [5] 1501-5 (2008).

11. R. Bao, C. Wang, L. Dong, R. Yu, K. Zhao, Z. L. Wang, and
C. Pan, "Flexible and Controllable Piezo-Phototronic Pressure Mapping Sensor Matrix by ZnO NW/p-Polymer LED Array,” Adv. Fun. Mater., 25 [19] 2884-91 (2015).

12. Y. J. Choi and H. H. Park, "A Simple Approach to the Fabrication of Fluorine-Doped Zinc Oxide Thin Films by Atomic Layer Deposition at Low Temperatures and an Investigation into the Growth Mode," J. Mater. Chem. C, 2 98-108 (2014).

13. F. Meng, S. Peng, G. Xu, Y. Wang, F. Ge, and F. Huang, "Optimizing the Discharge Voltage in Magnetron Sputter Deposition of High Quality Al-doped ZnO Thin Films," J. Vac. Sci. Technol., A, 33 [6] 061503 (2015).

14. J. Rousset, E. Saucedo, and D. Lincot, "Extrinsic Doping of Electrodeposited Zinc Oxide Films by Chlorine for Transparent Conductive Oxide Applications," Chem. Mater., 21 [3] 534-40 (2009).

15. H. Akazawa, "Modification of Transparent Conductive $\mathrm{ZnO}$ and Ga-doped $\mathrm{ZnO}$ Films by Irradiation with Electron Cyclotron Resonance Argon Plasma”, J. Vac. Sci. Technol. A, 29031304 (2011).

16. D. J. Lee, K. J. Kim, S. H. Kim, J. Y. Kwon, J. Xu, and K. B. Kim, "Atomic Layer Deposition of Ti-doped ZnO Films with Enhanced Electron Mobility," J. Mater. Chem. C, 1 4761-69 (2013).

17. A. Janotti and C. G. Van de Walle, "Native Point Defects in ZnO," Phys. Rev. B, 76 [16] 165202 (2007).

18. C. H. Park, S. B. Zhang, and S. H. Wei, "Origin of p-type Doping Difficulty in ZnO: The Impurity Perspective," Phys. Rev. B, 66 [7] 073202 (2002).

19. R. Vidya, P. Ravindran, H. Fjellvåg, B. G. Svensson, E. Monakhov, M. Ganchenkova, and R. M. Nieminen, "Energetics of Intrinsic Defects and Their Complexes in $\mathrm{ZnO}$ Investigated by Density Functional Calculations," Phys. Rev. B, 83 [4] 045206 (2011).

20. Y. Ma, G. T. Du, S. R. Yang, Z. T. Li, B. J. Zhao, X. T. Yang, T. P. Yang, Y. T. Zhang, and D. L. Liu, "Control of Conductivity Type in Undoped ZnO Thin Films Grown by Metalorganic Vapor Phase Epitaxy," J. Appl. Phys., 95 [11] 6268-72 (2004).

21. C. F. Yu, C. W. Sung, S. H. Chen, and S. J. Sun, "Relationship between the Photoluminescence and Conductivity of Undoped ZnO Thin Films Grown with Various Oxygen Pressures," Appl. Surf. Sci., 256 [3] 792-96 (2009).

22. G. Xiong, J. Wilkinson, B. Mischuck, S. Tüzemen, K. B. Ucer, and R. T. Williams, "Control of p- and n-type Conductivity in Sputter Deposition of Undoped ZnO," Appl. Phys. Lett., 80 [7] 1195 (2002).

23. A. V. Singh, R. M. Mehra, A. Wakahara, and A. Yoshida, "p-type Conduction in Codoped ZnO Thin Films," J. Appl. Phys., 93 [1] 396 (2003).

24. X. Liu, X. Wu, H. Cao, and R. P. H. Chang, "Growth Mechanism and Properties of ZnO Nanorods Synthesized by Plasma-Enhanced Chemical Vapor Deposition," $J$. Appl. Phys., 95 [6] 3141-47 (2004).

25. L. Cui, H. Y. Zhang, G. G. Wang, F. X. Yang, X. P Kuang, R. Sun, and J. C. Han, "Effect of Annealing Temperature and Annealing Atmosphere on the Structure and Optical Properties of $\mathrm{ZnO}$ Thin Films on Sapphire $\left(\begin{array}{llll}0 & 0 & 0 & 1\end{array}\right)$ Substrates by Magnetron Sputtering," Appl. Surf. Sci., 
258 [7] 2479-85 (2012).

26. Y. C. Cheng, Y. S. Kuo, Y. H. Li, J. J. Shyue, and M. J. Chen, "Stable p-type ZnO Films Grown by Atomic Layer Deposition on GaAs Substrates and Treated by PostDeposition Rapid Thermal Annealing," Thin Solid Films, 519 [16] 5558-61 (2011).

27. D. M. King, S. I. Johnson, J. Li, X. Du, X. Liang, and A. W. Weimer, "Atomic Layer Deposition of Quantum-Confined ZnO Nanostructures," Nanotechnology, 20 [19] 195401 (2009).

28. K. J. Qian, S. Chen, B. Zhu, L. Chen, S. J. Ding, H. L. Lu, Q. Q. Sun, D. W. Zhang, and Z. Chen, "Atomic Layer Deposition of $\mathrm{ZnO}$ on Thermal $\mathrm{SiO}_{2}$ and Si Surfaces Using $\mathrm{N}_{2}$-Diluted Diethylzinc and $\mathrm{H}_{2} \mathrm{O}_{2}$ Precursors," Appl. Surf. Sci., 258 [10] 4657-66 (2012).

29. J. Aarik, A. Aisla, T. Uustare, M. Ritala, and L. Markku, "Titanium Isopropoxide as a Precursor for Atomic Layer Deposition: Characterization of Titanium Dioxide Growth Process," Appl. Surf. Sci., 161 [3-4] 385-95 (2000).

30. Y. Wang, K. M. Kang, M. Kim, and H. H. Park, "Oxygen Vacancy-Passivated $\mathrm{ZnO}$ Thin Film Formed by Atomic Layer Deposition Using $\mathrm{H}_{2} \mathrm{O}_{2}$," J. Vac. Sci. Technol., A, 36 [3] 031504 (2018).

31. Y. Wang, K. M. Kang, M. Kim, and H. H. Park, "Low Temperature Method to Passivate Oxygen Vacancies in Un-doped ZnO Films Using Atomic Layer Deposition,” Thin Solid Films, 660 852-58 (2018).

32. R. W. Johnson, A. Hultqvist, and S. F. Bent, "A Brief Review of Atomic Layer Deposition: from Fundamentals to Applications," Mater. Today, 17 [5] 236-46 (2014).
33. S. H. K. Park and Y. E. Lee, "Controlling Preferred Orientation of ZnO Thin Films by Atomic Layer Deposition," J. Mater. Sci., 39 [6] 2195-97 (2004).

34. N. Fujimura, T. Nishihara, S. Goto, J. Xu, and T. Ito, "Control of Preferred Orientation for $\mathrm{ZnO}_{\mathrm{x}}$ Films: Control of Self-Texture," J. Cryst. Growth, 130 [1-2] 269-79 (1993).

35. S.-Y. Pung, K.-L. Choy, X. H. Hou, and C. X. Shan, "Preferential Growth of $\mathrm{ZnO}$ Thin Films by the Atomic Layer Deposition Technique," Nanotechnology, 19 [43] 435609 (2008).

36. D. M. King, X. H. Du, A. S. Cavanagh, and A. W. Weimer, "Quantum Confinement in Amorphous $\mathrm{TiO}_{2}$ Films Studied via Atomic Layer Deposition," Nanotechnology, 19 [44] 445401 (2008).

37. C. H. Ahn, Y. Y. Kim, D. C. Kim, S. K. Mohanta, and H. K. Cho, "A Comparative Analysis of Deep Level Emission in ZnO Layers Deposited by Various Methods," J. Appl. Phys., 105 [1] 013502 (2009).

38. C. Ton-That, L. Weston, and M. R. Phillips, "Characteristics of Point Defects in the Green Luminescence from Znand O-rich ZnO,” Phys. Rev. B, 86 [11] 115205 (2012).

39. K. Vanheusden, W. L. Warren, C. H. Seager, D. R. Tallant, J. A. Voigt, and B. E. Gnade, "Mechanisms behind Green Photoluminescence in ZnO Phosphor Powders," J. Appl. Phys., 79 [10] 7983-90 (1996).

40. E. S. Shim, H. S. Kang, J. S. Kang, J. H. Kim, and S. Y. Lee, "Effect of the Variation of Film Thickness on the Structural and Optical Properties of $\mathrm{ZnO}$ Thin Films Deposited on Sapphire Substrate Using PLD," Appl. Surf. Sci., 186 [1] 474-76 (2002). 